\title{
Adoption Level of Tribal Farmwomen about Horticultural Interventions under NAIP
}

\author{
Ramesh Kumar Damor ${ }^{1}$, Rajeev Bairathi ${ }^{2}$, S. S. Sisodia ${ }^{2}$, \\ Prakash Panwar ${ }^{3}$ and Vikas Kumar ${ }^{4 *}$
}

${ }^{1}$ Krishi Vigyan Kendra, Pratapgarh, ${ }^{2}$ Department of Extension Education, Rajasthan College of Agriculture, MPUAT, Udaipur, India

${ }^{3}$ Department of Extension Education and Communication Management, College of

Community and Applied Sciences, MPUAT, Udaipur - 313001, India

${ }^{4}$ Department of Extension Education, SKNAU, Jobner, India

*Corresponding author

\section{A B S T R A C T}

Keywords

NAIP, Adoption, Farmwomen, Horticultural interventions etc.

\section{Article Info}

\section{Accepted:}

04 September 2019

Available Online:

10 October 2019
The present study was conducted in purposely selected Southern area of Rajasthan as NAIP was implemented in four districts of Southern Rajasthan viz., Banswara, Dungarpur, Sirohi and Udaipur. Out of these, two districts i.e. Banswara and Dungarpur were selected for present investigation on the basis of maximum concentration of tribal population. To have an equal representation of survey area, all the 25 villages in which the NAIP programme implemented were included in the proposed study. Ten respondents were drawn from each village with the help of random sampling technique. Thus, a sample of 250 tribal farm women who belonged to beneficiary farm families was selected as respondents for the present study. On the basis of overall adoption derived by the tribal farm women on horticulture interventions under NAIP, three categories were formulated viz., low $(<14.8)$, medium (14.9-21.3) and high (>21.3) level of adoption on horticulture interventions under NAIP. The results shows that out of 250 sample respondents, 70.40 per cent tribal farm women were having medium level of adoption of horticulture interventions under NAIP followed by 15.00 per cent with high and 14.00 per cent farm women with low level of adoption of horticulture interventions under NAIP.

\section{Introduction}

Women form an important sector of our society. They constitute about half of the population of the country. Rural areas encompass 80.00 per cent of the total women population. Women perform multiple roles, both in agriculture and home. They perform almost 60.00 per cent of all working hours, receive 10.00 per cent of the word's income and own even less than 1 per cent of the world's property. Socio-cultural roles have 
cast women in a secondary role for a long time. Women's work remains outside the cash sector. She works from dawn to dusk but she has to depend on her male counterpart for meeting out her financial requirement.

The ever-increasing price line and the needs of the family have necessitated women to take up gainful employment. Empowerment of women could be in any sphere of life i.e. legal, social, political and economic, but economic empowerment is the ladder for all the other empowerment.

As women are being increasingly seen as an important index for the development of nation, it is necessary to develop entrepreneurship among women and encourage them to take up independent income generating activities so that the significant work force of the country may be utilized more efficiently in the progress of the country.

A six year ambitious agricultural research programme was launched in India on $6^{\text {th }}$ July, 2006, which was named as National Agricultural Innovation Project (NAIP). The project focused on innovations in agricultural technology. It was expected that project would facilitate an accelerated and sustainable transformation of the Indian agriculture so that it can support poverty alleviation and income generation. This was achieved through collaborative development and application of agricultural innovations by the public organizations in partnership with farmers' groups, the private sector and other stakeholders. It is seemed as a prestigious World Bank assisted project which helped in making Indian Agriculture a profitable venture.

In the present project proposal, two models (i) Horticulture based Integrated Farming system (IFS) and (ii) Livestock based Integrated Farming system (IFS) model with judicious mix of proven need assessed technologies appropriate for small and marginal farmers encompassing end to end approach was planned and implemented for development of appropriate replicable model. To the best of the knowledge to the researcher, no study so for has been undertaken by any researcher regarding the Empowerment of tribal farm women through horticultural interventions under NAIP in Southern Rajasthan.

\section{Materials and Methods}

The NAIP was implemented in four districts of Southern Rajasthan viz-Banswara, Dungarpur, Sirohi and Udaipur. Out of these four districts, two districts i.e. Banswara and Dungarpur were selected for present investigation on the basis of maximum concentration of tribal population.

There were total four clusters, two in Banswara and two in Dungarpur where NAIP was implemented. All these four clusters were included in the present research study. In all, there were twenty five villages in which the NAIP programmewas running. To have an equal representation of survey area, all the 25 villages were included in the proposed study.

Sample of tribal farm women was drawn from these beneficiary families. Ten respondents were drawn from each village with the help of random sampling technique. Thus, a sample of 250 tribal farm women who belonged to beneficiary farm families was selected as respondents for the present study. To measure the adoption of the respondents about recommended horticultural interventions under NAIP, adoption test was developed. Total twenty interventions regarding horticulture were included in the schedule.

To determine the extent of adoption of respondents about each aspect, mean per cent score was worked out and ranked accordingly. 
To find out the difference in adoption between respondents of Banswara and Dungarpur districts, ' $Z$ ' test was applied.

\section{Results and Discussion}

To classify the respondents on the basis of overall adoption derived by the tribal farm women on horticulture interventions under NAIP, three categories were formulated viz., low (<14.8), medium (14.9-21.3) and high (>21.3) level of adoption on horticulture interventions under NAIP.

The results shows that out of 250 sample respondents, 70.40 per cent tribal farm women were having medium level of adoption of horticulture interventions under NAIP followed by 15.00 per cent with high and 14.00 per cent farm women with low level of adoption of horticulture interventions under NAIP.

District-wise analysis shows that about 12.00 , 70.70 and 17.30 per cent of farm women in Dungarpur district and 17.00, 70.00 and 13.00 per cent of tribal farm women in Banswara district were having low, medium and high level of adoption of horticulture interventions under NAIP, respectively. From the data, it can be concluded that majority of respondents $(70.40 \%)$ fall under category of medium level of adoption of horticulture interventions under NAIP (Table 1).

\section{Aspect wise adoption of horticulture interventions}

The data presented on adoption of various horticulture interventions in Table 2 indicates that in rank hierarchy, horticulture interventions viz. 'Weed management practices' was ranked first by the respondents with mean per cent score of 61.6 per cent, followed by 'Improved harvesting implements', 'Duster' and 'Marketing
Process' with mean per cent score of 59.6, 55.6 and 54.6, respectively. Data also shows that least adopted horticulture interventions were 'Integrated nutrient management' and 'Grafting \& cutting' which were ranked at $19^{\text {th }}$ and $20^{\text {th }}$ in rank hierarchy respectively.

District-wise data related to adoption of horticulture interventions shows that 'Improved harvesting implements' (63.33 MPS), 'Weed Management Practices' (58.66 MPS) and 'Marketing Process' (56.60 MPS) in Dungarpur district while, 'Sprayer' (52.00 MPS), 'Marketing Process' (51.50 MPS) and 'Nursery raising of vegetables in poly house' (49.00 MPS) in Banswara district were major horticulture interventions which respondents adopted and therefore these were ranked $1^{\text {st }}$, $2^{\text {nd }}$ and $3^{\text {rd, }}$ respectively in rank hierarchy.

\section{Difference in adoption level of respondents of Banswara and Dungarpur districts}

Table 3 indicates that the calculated ' $Z$ ' value was found to be less than its tabulated value. The null hypothesis $\left(\mathrm{NH}_{01}\right)$ was therefore accepted and alternate hypothesis $\left(\mathrm{RH}_{1}\right)$ was rejected.

It reveals that there was no-significant difference in level of adoption between respondents of Banswara and Dungarpur districts about Horticulture interventions under NAIP. Though, the mean value further indicates that respondents of Dungarpur had little higher adoption than respondents of Banswara district about Horticulture interventions under NAIP.

Non-significant difference between the districts may be because of the fact that both the districts are located in tribal area with almost similar facilities and infrastructure for use in the study area and the project NAIP was implemented in both the districts with similar pattern and time. 
Table.1 Adoption level of tribal farm women of horticulture interventions under NAIP

\begin{tabular}{|l|l|l|l|l|l|l|l|l|}
\hline S.No & Categories & \multicolumn{9}{|c|}{ Dungarpur } & \multicolumn{2}{|c|}{ Banswara } & \multicolumn{2}{|c|}{ Overall } \\
\cline { 3 - 9 } & & f & \% & f & \% & f & $\%$ \\
\hline 1. & Low $(<14.8)$ & 18 & 12.00 & 17 & 17.00 & 35 & 14.00 \\
\hline 2. & $\begin{array}{l}\text { Medium(14.9 } \\
\text { 21.3) }\end{array}$ & to & 106 & 70.70 & 70 & 70.00 & 176 & 70.40 \\
\hline 3. & High $(>21.3)$ & 26 & 17.30 & 13 & 13.00 & 39 & 15.60 \\
\hline Total & & $\mathbf{1 5 0}$ & $\mathbf{1 0 0}$ & $\mathbf{1 0 0}$ & $\mathbf{1 0 0}$ & $\mathbf{2 5 0}$ & $\mathbf{1 0 0}$ \\
\hline
\end{tabular}

$\mathrm{f}=$ Frequency, $\%=$ per cent

Table.2 Aspect wise adoption of horticulture interventions

\begin{tabular}{|c|c|c|c|c|c|c|c|}
\hline \multirow{2}{*}{$\begin{array}{l}\text { S. } \\
\text { No. }\end{array}$} & \multirow[t]{2}{*}{ Horticulture interventions } & \multicolumn{2}{|c|}{ Dungarpur } & \multicolumn{2}{|c|}{ Banswara } & \multicolumn{2}{|c|}{ Overall } \\
\hline & & MPS & Rank & MPS & Rank & MPS & Rank \\
\hline 1. & Establishment of orchard & 39.00 & 16 & 43.50 & 8 & 40.8 & 15 \\
\hline 2. & Cultivation of vegetables & 44.66 & 9 & 41.50 & 15 & 43.4 & 12 \\
\hline 3. & Grafting \& cutting & 33.00 & 19 & 30.50 & 20 & 32 & 20 \\
\hline 4. & $\begin{array}{l}\text { Nursery raising of vegetables in poly } \\
\text { house }\end{array}$ & 42.00 & 13 & 49.00 & 3 & 44.8 & 9 \\
\hline 5. & Inter cropping & 56.33 & 4 & 48.50 & 4 & 53.2 & 5 \\
\hline 6. & Seed replacement & 40.00 & 15 & 41.00 & 16 & 40.4 & 16 \\
\hline 7. & Improved agricultural equipments & 44.33 & 10 & 40.50 & 17 & 42.8 & 13 \\
\hline 8. & Sprayer & 52.00 & 5 & 52.00 & 1 & 52.0 & 6 \\
\hline 9. & Duster & 48.66 & 6 & 42.00 & 12 & 55.6 & 3 \\
\hline 10. & Soil test based fertilizer application & 36.66 & 17 & 37.50 & 18 & 37.0 & 18 \\
\hline 11. & Integrated nutrient management & 30.66 & 20 & 41.66 & 13 & 34.8 & 19 \\
\hline 12. & Integrated pest management & 45.66 & 8 & 42.50 & 10 & 44.4 & 10 \\
\hline 13. & Weed Management practices & 58.66 & 2 & 37.50 & 18 & 61.6 & 1 \\
\hline 14. & Seed production technologies & 43.66 & 11 & 41.66 & 13 & 43.8 & 11 \\
\hline 15. & Improved harvesting implements & 63.33 & 1 & 42.50 & 10 & 59.6 & 2 \\
\hline 16. & Installation of drip unit, PVC pipelines & 41.66 & 14 & 43.36 & 9 & 42.4 & 14 \\
\hline 17. & Nutrigarden & 36.33 & 18 & 43.60 & 7 & 39.2 & 17 \\
\hline 18. & Post harvest technologies & 43.00 & 12 & 48.00 & 5 & 45.0 & 8 \\
\hline 19. & Grading of produce & 46.66 & 7 & 47.00 & 6 & 46.8 & 7 \\
\hline 20. & Marketing Process & 56.66 & 3 & 51.50 & 2 & 54.6 & 4 \\
\hline
\end{tabular}

MPS=mean per cent score 
Table.3 Difference in adoption level of respondents of Banswara and Dungarpur districts

\begin{tabular}{|l|l|l|l|l|}
\hline S. No. & Respondents & Mean & S.D. & 'Z' value \\
\hline 1. & Dungarpur district & 18.12 & 2.99 & $\mathbf{0 . 1 0 7 N S}$ \\
\hline 2. & Banswara district & $\mathbf{1 8 . 0 9}$ & $\mathbf{3 . 4 5}$ & \\
\hline
\end{tabular}

$\mathrm{n}=250$

The results shows that out of 250 sample respondents, 70.40 per cent tribal farm women were having medium level of adoption of horticulture interventions under NAIP followed by 15.00 per cent with high and 14.00 per cent farm women with low level of adoption of horticulture interventions under NAIP. District-wise analysis shows that about 12.00, 70.70 and 17.30 per cent of farm women in Dungarpur district and 17.00, 70.00 and 13.00 per cent of tribal farm women in Banswara district were having low, medium and high level of adoption of horticulture interventions under NAIP, respectively. From the data, it can be concluded that majority of respondents $(70.40 \%)$ fall under category of medium level of adoption of horticulture interventions under NAIP.A Non-significant difference in adoption level of respondents of Dungarpur and Banswara districts was observed about horticultural interventions under NAIP.

\section{References}

Dave, R., Godawat, A., Soni, R.L. 2011.Adoption of okra production technologies in tribal women promoted under NAIP. Rajasthan Journal of Extension Education 19: 117-125.

Kumar, S., Lal, H. and Bunkar, H.S. 2014. Extent of adoption of recommended coriander production technology by the farmers. Indian Journal of Extension Education and Rural Development 22: 177-179.

Razzak, M. A., Alam, M. S., Fatema, U., Parvin, T., Islam,M. A., and Ali, M. M. 2015. Eco-friendly management of major insect pests of brinjal with polyculture crop system. Scholary Journal of Agricultural Sciences 5: 5358.

Sharma, 2008. A study on Adoption of improved technology of papaya by papaya growers in Anand district of Gujarat State. M.Sc. (Agri.) thesis, Gujarat Agriculture University, Anand.

Soni, M. Shrivastava, K.K. and Verma, L.R. 2013. Adoption behaviour of recommended cauliflower production technology by the cauliflower growers. Agriculture Update 8: 197-200.

\section{How to cite this article:}

Ramesh Kumar Damor, Rajeev Bairathi, S. S. Sisodia, Prakash Panwar and Vikas Kumar. 2019. Adoption Level of Tribal Farmwomen about Horticultural Interventions under NAIP. Int.J.Curr.Microbiol.App.Sci. 8(10): 7-11. doi: https://doi.org/10.20546/ijcmas.2019.810.002 